Abstracta Iranica Abstracta Iranica

Revue bibliographique pour le domaine irano-aryen

Volume 22 | 2001

Comptes rendus des publications de 1999

\title{
Half of the World: The Social Architecture of Safavid Isfahan, 1590-1722. Los Angeles, Mazda, 1999, 206 p.
}

\section{David Durand-Guédy}

\section{OpenEdition}

1 Journals

Édition électronique

URL : http://journals.openedition.org/abstractairanica/36695

DOI : 10.4000/abstractairanica.36695

ISSN : 1961-960X

\section{Éditeur :}

CNRS (UMR 7528 Mondes iraniens et indiens), Éditions de l'IFRI

\section{Édition imprimée}

Date de publication : 15 mai 2001

ISSN : 0240-8910

\section{Référence électronique}

David Durand-Guédy, " Half of the World: The Social Architecture of Safavid Isfahan, 1590-1722.

Los Angeles, Mazda, 1999, 206 p. », Abstracta Iranica [En ligne], Volume 22 | 2001, document 296, mis en ligne le 16 février 2010, consulté le 12 octobre 2020. URL : http://journals.openedition.org/ abstractairanica/36695; DOI : https://doi.org/10.4000/abstractairanica.36695

Ce document a été généré automatiquement le 12 octobre 2020.

Tous droits réservés 


\title{
Half of the World: The Social Architecture of Safavid Isfahan, 1590-1722. Los Angeles, Mazda, 1999, $206 \mathrm{p}$.
}

\author{
David Durand-Guédy
}

1 Ce livre, court mais dense, est le neuvième titre de la prestigieuse collection « Islamic Art and Architecture Series» (A. Daneshvari, R. Hillenbrand, B. O'Kane). Le projet de l'A. n'est pas de refaire une étude sur l'architecture des monuments de la « Moitié du monde " (les travaux de qualité sont nombreux), mais plutôt de montrer par qui et pourquoi ces monuments ont été construits. En dernière instance, son but est de parvenir à une meilleure compréhension de la société locale, du système politique, économique et religieux mis en place par Šāh 'Abbās I, par le biais de l'étude du plan de la ville et des bâtiments qui la structurent. Dans cette nouvelle approche («social architecture »), la «ville est un texte» (p.xv) et il faut donc l'étudier comme tel: retrouver les thèmes, montrer les articulations, définir les enjeux, l'intérêt et la portée du texte.

2 Pour mener son projet à bien, Blake utilise des sources persanes et européennes, en premier lieu desquelles viennent respectivement Eskandar Monšĩ et Chardin. Une lecture attentive lui permet d'établir, en guise d'introduction, quelques résultats importants sur la chronologie des travaux et la population de la ville. Si 'Abbās I décida de déplacer le centre névralgique de la Meydān Hārūn Velāyat à la Meydān Naqšs-e Jahān dix ans après son installation dans la ville (et non aussitôt après comme on le croyait jusqu'alors), ce fut pour manifester le succès de ses réformes économiques et politiques. Ensuite, l'A. classe les monuments de la ville en trois chapitres, selon leurs fonctions (politique, économique, religieuse). Cette division thématique recoupe le découpage chronologique dans la mesure où, selon les conclusions de l'A., 'Abbās I est le principal promoteur de l'architecture politique (palais impérial de la Meydān Hārūn Velāyat, palais de Naqš-e Jahān, Meydān Naqšse Jahān), ‘Abbās II de l'architecture 
économique (achèvement du bazar) et Solțān Hoseyn de l'architecture religieuse (madrese-ye Soltānī). En tout, 173 éléments de l'urbanisme d'Isfahan (jardin, palais, mosquées, caravansérails, ponts, etc.) sont référencés, situés sur des cartes d'une grande clarté et décrits avec soin, pour mieux faire ressortir les mécanismes du pouvoir safavide (judicieusement comparé au pouvoir ottoman et moghol), le rôle des grands marchands, des émirs, des femmes, des Indiens, des Hollandais, bref des différents éléments de la société d'Isfahan au Grand Siècle.

INDEX

Thèmes : 5.1. Monde iranophone

\section{AUTEURS}

DAVID DURAND-GUÉDY

IFRI - Téhéran 